\title{
A Probe into the Female Psyche in Margaret Atwood's The Robber Bride
}

\author{
C. Muralidara Kannan* \\ Assistant Professor, PG \& Research Department of English, Government Arts College, Coimbatore, India; \\ drcmuralidara@gmail.com
}

\begin{abstract}
Margarat Atwood's works are noted for her wisdom, intelligence and strikingly powerful craft of writing that few dare to embark in the realm of Canadian literature. The Robber Bride, her eighth novel, has been taken up here for an analysis and discussion thereof. She has proved her mettle as a woman writer of a class apart by delving deep into the unfathomable caverns of female psyche. Her attempt of probing the woman's psyche turns successful. Giving the plot in a nutshell, the discussion commences focusing on the psyching temperament of the three major characters, Tony, Charis, Roz and giving an emphasis on the vile Zenia. For, it is the story of Zenia. The female psyche with its ups and downs, hitherto unknown innermost intricacies and personality types of the characters has come up for analysis. This paper is only a humble attempt to explore the female psyche in The Robber Bride. There are several other ways of probing the same issue because the novel is a reservoir of many avenues to unfold.
\end{abstract}

Keywords: Female Psyche, Psyching Temperament of Women, Psychical Wreckage

\section{Introduction}

Atwood is an asset in the inimitable world of Canadian literature who has, to her credit, more than a score of books of popularity--novels, short stories, a bouquet of poems and a length of literary criticism. The award winning writer's indomitable works have reached many corners of the globe and have seen so many translations. The Robber Bride turns out to be the eighth novel of Margaret Atwood. Atwood's works are noted for her wisdom, intelligence and strikingly powerful craft of writing that few dare to embark in the realm of Canadian literature. Any reader of her previous novels viz. The Handmaid Tale or Cat's Eye would have nourished their mind and undoubtedly relished reading the work as such. The Robber Bride is seriously, sentimentally and shockingly unique; and despite a counter part of Grimm's book, has terribly shaken the strong hold of women world. Atwood, in penning the portraits of the women characters in The Robber Bride, has proved her mettle as a woman writer of a class apart by delving deep into the unfathomable caverns of female psyche.

It is usually stated that the most complex phenomenon is human psyche and to unravel its mysteries is a mammoth task. Many have miserably failed in their attempt. One may ask whether there is, in actually, a major difference between the male and female psyche as one probes the subject of human psyche. Of course, there is. A close reading of The Robber Bride does reveal the difference. The psyche of a woman is indeed a zigzag puzzle, a labyrinth and a complicated knot to unfasten. Eventually, a seasoned, experienced hand of adept dexterity is required to unfasten it. That is what Atwood has attempted here and is successful in her attempt.

Well, it is the story of three protagonists, Tony, Charis and Roz; particularly it is the story of Zenia, the trio's friend. A friend or fiend? Zenia who cunningly, stealthily and unobtrusively snatches away the men of this trio,

*Author for correspondence 
dies in a bomb-blast. To the surprise of the trio, on an unfortunate day, when the three are at the Toxique-their rendezvous restaurant, the dead Zenia comes alive, in flesh and blood. Each of the trio grows nostalgic and taking turns relate their nightmarish experiences with Zenia in the three different segments of the novel christened, Black Enamel, Weasel Nights, and The Robber Bride. Individually, Tony, Charis and Roz conceive a black murder of Zenia. Are they incapable of executing it? Or Zenia turns so powerful to get rid of from this world once for all? The much awaited, the real death of Zenia takes place rather late, when all the men have already been used up by her. One can analyze it in any angle, all roads will lead to the same destination, the dreadful, destructive debauchery of Zenia.

The very first state of female psyche with its ups and downs, psychical tension equated to surface tension with an imbalance of secure and insecure feelings and the darker side of life gets exposed in the character of the first of the trio, Tony, the History Professor, when they have just seen the dead Zenia coming alive:

Tony felt safe this morning, safe enough. But she doesn't feel safe now. Everything has been called into question. Even in the best of times, the daily world is tenuous to her, a thin iridescent skin held in place by surface tension. She puts a lot of effort into keeping it together, her willed illusion of comfort and stability, the words flowing from left to right, the routines of love; but underneath is darkness. Menace, chaos, cities aflame, towers crashing down, the anarchy of deep water [1].

Tony's state of mind is still waters at surface level and turbulent undercurrent. A woman is always strong enough to maintain this poise externally, however turbulent her inner being is. But in the case of a man, however strong he is, with his rock like frame, maintaining an exterior inconspicuous turns out to be a futile attempt; he makes it transparent. The so called physically weak woman has a strong psyche, unfathomably intricate to anybody, including her own men. There are monumentally remarkable moments when the second of the trio, Charis maintains a psychic state of split-personality--Karen and Charis and vice versa. Continuously tormented by the incest of her uncle Vern, soon after her mother's death, Karen turns into Charis:

All she can do is split in two ; all she can do is turn into Charis, and float out of her body and watch Karen, left behind with no words, flailing and sobbing....But she could never kill. She isn't hard enough...But some of her power stays there in Karen's hands. Her healing power, her killing power. (295-96) [1].

Karen, one of the two of the split, who has been intolerably yielding to the sexual advances of Uncle Vern, timidly and meekly, grows a powerful protector for the tender and procrastinating Charis. Rightly said, she turns a healing and killing power for Charis, the second of the split. If Charis has not assumed the split of Karen, she will not have Zenia killed. Yes. Towards the end of the novel, especially in the last segment called Outcome one finds that it is her first of the split, Karen who pushes Zenia into the swimming pool and finishes her off -- killed Zenia and healed Charis, healed the wounds of Tony and Roz too.

The third of the trio, Roz is gullible, over confident and cherishes a kind of self-annihilating pride that is fortunately missing in her friends, Tony and Charis. Despite the warning of her friends, she turns headlong in taking in Zenia, the goat-skinned wolf. Her irrationally bold psyche gets revealed when she broods:

Roz reminded herself. You walked into it your eyes open. What led you on? ... She knows what it was now. It was Pride, deadliest of the Seven Dead-lies; the sin of Lucifer, the well spring of all others. Vainglory, false courage, bravado. She must have thought she was some kind of lion-tamer, some kind of a bull-fighter; she could succeed where her two friends failed. Why not? . . . She thought she could handle Zenia [1].

It is a pity Roz, the business whiz gets cheated to the core. The debauchery of Zenia gives Roz a deadly blow, financially, personally and above all psychically. Roz becomes miserable. The psychical wreckage of Roz is deeper and deadlier than that of her friends, for the lusty and flesh thirsty jaw of the wolf devours her men, Roz's husband and her son. True, she walked into that danger with her eyes open. It was a wanton invitation against protective precaution. As it goes unheeded, it turns out to be a fatal blow for her, for her fatal flaw. Each of the trio has lost her psychological balance, each differently on different occasions, on receiving the fatal blow from Zenia. It is only their friendship and Toxique unites them even after Zenia's death.

Well, what about Zenia's psyche? For, wherever one pokes, the novel is basically Zenia's story. Yes. It is Zenia who has got a lion-share, literally. The most unfathomable psyche of the women characters in the story is undoubtedly, Zenia's. It's machinations and maneuverings are mysterious and turn out to be brain teasers not only to the men in the novel, but the women 
themselves. Atwood has given the reader a glimpse of Zenia's mind and how does it work in the very beginning, the first segment named Onset itself:

Zenia would lie. She would lie earnestly, with a catch in her voice, a quaver of suppressed grief, or she would lie haltingly, as if confessing; or she would lie with cool defiant anger .... it is the mix of domestic image and mass bloodshed ... appreciated by Zenia, who enjoyed such turbulence, such violent contradictions. More than enjoyed: created. Why is still unclear [1].

It is said, "...man is the only species that engages in warfare and other acts of collective violence against his own kind. .." [2]. Here, in The Rober Bride, the species is woman. Woman in warfare with women. A woman's rival is only another woman. Zenia is one such living with the trio, even after her death. Zenia's psyche chases so many things--money, men, women, just for fun--lust for fun, all the same nurturing all the vile tempers and evil intents with the creamy layer of friendship turning the core of the cake carcinogenic. A writer appropriately comments:

Her interest is any combination of money, romance, and excitement. The scent of these accommodations will have her rising like a cobra from a wicker basket. The provider of such diversions occupies center stage in her life, but his identity is unimportant to her, and it's a temporary position. Nobody can amuse her forever. All pied pipers eventually fade into the past [3].

Close to the end of the story, one could see how heartlessly Zenia blackmails Roz. Zenia shows her true colour. Larry, Roz's son gets hooked up in a drug deal. Zenia exploits both the situation and the person eventually and brings about a lethal blow to the closest of the relations. Growing ferocious to the resentful Roz, Zenia yells out:
Zenia frowns. "Money is too important to you, Roz," she says. "What I was really offering you was protection for yourself. Not for Larry. But you aren't worth protecting. Here's the real truth, then, Yes, I'm screwing Larry. Larry is my primary pusher... He thinks I need him [1].

Zenia's behaviour sounds diabolically against the established notion of women. A social psychologist David G. Winter observes, "Women display their power needs in a more restrained manner, congruent with traditional societal restraints on women's behavior" [4]. Can Zenia be judged based on this fact? Certainly not. She doesn't fit into any norms. Neither an inquisitive reader nor a critic could be a complete success in his analysis of the psyche of Zenia. For, the plot is woven with such an intricacy and characterization, with devices like flashback, conflicts external and internal; details of history and war; battles, the folly of human relations, affairs, love, lust etc. that it is very difficult come out this cul de sac. Hence, the novel will, to some extent, stay a mystery. For, it is the story of Zenia.

\section{References}

1. Atwood M. The Robber Bride. New York: Bantam Books, 1995.

2. Coleman C.J., and Broen E.W. Abnormal Psychology and Modern Life, India: D. B. Taraporevala, 1972. pp. 613.

3. Shannon, R.L. The Predatory Female, Reno, Nevada: Banner Books Inc., 1997. pp. 11-12.

4. Winter, D.G. "The Power Motive in Women-and Men." Journal of Personality and Social Psychology, Vol. 54(3), p. 510-519, 1988. 